\title{
O027: Compliance of jordanian registered nurses with infection control guidelines: a national population-based study
}

\author{
OM Al-Rawajfah ${ }^{*}$, IM Hweidi², M Alkhalaileh', YS Khader ${ }^{3}$, SA Alshboul ${ }^{4}$ \\ From 2nd International Conference on Prevention and Infection Control (ICPIC 2013) \\ Geneva, Switzerland. 25-28 June 2013
}

\begin{abstract}
Introduction
The CDC recommends that educating health-care workers regarding infection control measures is the first high priority strategy to prevent and control Health Care Related Infection (HCRIs). The CDC recommends periodic assessment of knowledge and adherence to infection control guidelines as a high priority. Such guidelines are updated and published frequently.
\end{abstract}

\section{Objective}

This national study aims to assess the compliance of Jordanian RNs with standard Infection Control (IC) guidelines.

\section{Method}

Cross-sectional, descriptive design was used. Proportional-multistage, probability sampling was used to obtain a sample of $10 \%$ of all staff nurses working in Jordanian hospitals. The final sampling frame consisted of 103 hospitals from different healthcare sectors. Standardized self-reported instruments used to evaluate the compliance. In the current study the reliability coefficient of the tool was 0.88 . Ethical approval was obtained from participating hospitals. Informed consent was obtained from participating nurses.

\section{Results}

A $889 \mathrm{RN}$ from 22 hospitals were participated in the study with a response rate of $89.4 \%$, of which $52.6 \%$ were females, $81.9 \%$ were holding a Bachelor degree.

Adult health nursing, Al al-Bayt University/ Faculty of Nursing, Mafraq, Jordan

Full list of author information is available at the end of the article
The mean age was 29.0 years $(S D=5.9)$ and the mean years of experience was 6.9 years $(S D=5.8)$. The overall mean compliance score was $119.9(S D=14.3)$. Nurses who received IC training in the hospital demonstrated higher compliance $(M=120.2, S D=13.6)$ than those who never received such training $(M=115.8, S D=$ $15.2), p<0.001$. Nurses who work in university affiliated hospitals demonstrated higher compliance than other types of hospital $(p<0.001)$.

\section{Conclusion}

This study demonstrated the necessity of establishing need-based IC programs especially for newly employed nurses. This study provides information about infection control practices in various healthcare sectors in Jordan. Results from this study expected to guide efforts to develop educational tools, programs, and curricula to improve infection control practices in the Jordan.

\section{Disclosure of interest}

O. Al-Rawajfah Employee of no conflicts of interest, Grant/Research support from no conflicts of interest, I. Hweidi Employee of no conflicts of interest, Grant/ Research support from no conflicts of interest, $M$. Alkhalaileh Employee of no conflicts of interest, Grant/ Research support from no conflicts of interest, Y. Khader Employee of no conflicts of interest, Grant/Research support from no conflicts of interest, S. Alshboul Employee of no conflicts of interest, Grant/Research support from no conflicts of interest.
Author details
${ }^{1}$ Adult health nursing, Al al-Bayt University/ Faculty of Nursing, Mafraq,
Jordan. ${ }^{2}$ Adult health nursing, Jordan. ${ }^{3}$ Department of Public Health,
Community, Family Medicine/Faculty of Medicine, Jordan university of 
Science and Technology, Irbid, Jordan. ${ }^{4}$ Faculty of Faculty of Applied Medical

Sciences, Jordan university of Science and Technology, Irbid, Jordan.

Published: 20 June 2013

doi:10.1186/2047-2994-2-S1-027

Cite this article as: Al-Rawajfah et al:: O027: Compliance of jordanian registered nurses with infection control guidelines: a national population-based study. Antimicrobial Resistance and Infection Control 2013 2(Suppl 1):027.

Submit your next manuscript to BioMed Central and take full advantage of:

- Convenient online submission

- Thorough peer review

- No space constraints or color figure charges

- Immediate publication on acceptance

- Inclusion in PubMed, CAS, Scopus and Google Scholar

- Research which is freely available for redistribution

Submit your manuscript at www.biomedcentral.com/submit
() Biomed Central 